Article

\title{
Logic of Identity and Identity of Contradiction
}

Rudi Capra

\begin{abstract}
Western philosophy has mainly developed in accordance with the three laws of identity, noncontradiction and excluded middle, also known as "laws of thought". Since Zen Buddhism often violates these apparently indisputable logical principles, a superficial reading may induce the idea that Zen Buddhism is a completely irrational, illogical doctrine. In this essay, I argue that Zen Buddhism is not absurd or illogical. Conversely, it relies on a different logic, which is perfectly consonant with the Buddhist view of the world.
\end{abstract}

Keywords: Zen, logic, identity, contradiction

$\mathrm{O}$ n the one hand, philosophical discourse in the West has mainly developed in accordance to the fundamental axioms known as "laws of thought," whose earliest explicit formulation (even if not systematically organized) appeared in the Platonic-Aristotelian corpus. These rules are the law of identity, the law of noncontradiction, and the law of excluded middle. In Classical philosophy and logic, these principles were conventionally credited with underlying any valid thought process.

It has been pointed out, on the other hand, that the tradition of Zen Buddhism systematically violated these apparently self-evident axioms, resulting in anti-logical or a-logical conclusions which were frequently judged (especially by Western readers) as paradoxical, or even nonsensical. Thus, Zen Buddhism is often regarded as a cult of the absurd for its emphasis on the narrowness of the ordinary mind (limited by logical constraints) in respect to the openness of the state of "pure mind" or "no mind."

In this essay, I argue that Zen Buddhism, far from being a cult of the absurd, is only apparently nonsensical and irrational. In order to do that, I first expound, in detail, the three laws of thought as they were conceived in the original Platonic-Aristotelian corpus. Successively, I explain why these principles are openly rejected in the Buddhist view. Lastly, I argue that Zen

(C) 2017 Rudi Capra

http://www.kritike.org/journal/issue 21/capra december2017.pdf

ISSN 1908-7330

$(c c)$ BY-NC-ND 


\section{IDENTITY AND CONTRADICTION}

is not plainly illogical, but rather relies on a different logic that cannot merely be dismissed as absurd.

\section{The Three Laws of Thought}

George Boole (1854) was the first to define the principles of identity, noncontradiction, and excluded middle as "laws of thought" in his second monograph on algebraic logic. However, the implicit adoption and repeated application of these laws in the construction of logical and philosophical (even ontological) theories has been central throughout the history of Western thought. In fact, their earliest known formulation dates back to the Classical age of ancient Greece.

In the context of Greek philosophy, there is a relationship of conceptual filiation between Parmenides, Plato, and Aristotle, expressly revealed by Plato, who refers to the older writer as "father Parmenides"

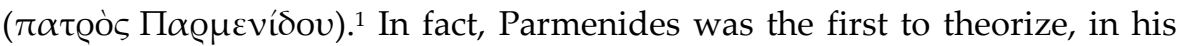
philosophical poem On Nature, the mutual exclusivity of "What-is" and "What-is-not," establishing then, and once for all, a(n) (onto)logical notion of identity as an irreducible, fundamental feature of What-is, being necessarily identical to itself, and necessarily different from What-is-not. ${ }^{2}$

This achievement was not at all banal, nor undisputed, since before Parmenides, another influential philosopher, Heraclitus, in a homonymous philosophical treatise, had described the universe (kosmos) as a dynamic flux in which all identities, despite being apparently unchangeable and opposite, are actually complementary components of the cosmic unity.

Unsurprisingly, both Heraclitus' and Parmenides' positions are briefly compared in Plato's Theaetetus where the law of identity (hereafter referred to as LID) is first formulated. In the text, Socrates mediates between the Heraclitean doctrine of flux and the Parmenidean doctrine of motionlessness, suggesting that Parmenides, despite his obscurity, seems worthy of reverence or veneration ( $\alpha$ i̇ooios). Then, even if roughly exposed, a basic concept of identity, and ipso facto a basic concept of difference (that is, non-identity), are undoubtedly present in this dialogue:

Socrates: Now take a sound and a color. First of all, don't you think this same thing about both of them, that they both are?

Theaetetus: I do.

\footnotetext{
${ }^{1}$ Plato, Sophist, trans. by Nicholas P. White, in Plato: Complete Works, ed. by John M. Cooper and Douglas S. Hutchinson (Indianapolis: Hackett, 1997), 241d.

2 Parmenides, On Nature (fragments), in Hermann Diels and Walther Kranz, Die Fragmente der Vorsokratiker (Berlin: Weidmann, 1974), fragments 2-3.

(c) 2017 Rudi Capra

https://www.kritike.org/journal/issue 21/capra december2017.pdf

ISSN 1908-7330
}

(c) BY-NC-ND 
Socrates: Also that each of them is different from the other and the same as itself?

Theaetetus: Of course.

Socrates: And that both together are two, and each of them is one?

Theaetetus: Yes, I think that too. ${ }^{3}$

The logical form of the LID can then be expressed by the logical notation $\mathrm{A}=\mathrm{A}$, meaning that any conceivable considered entity is necessarily identical to itself. The LID, even if not explicitly formulated there, is repeatedly employed in Aristotle's works, for instance when he attempts to demonstrate the validity of the second of these laws, the law of noncontradiction, which is nonetheless ultimately dependent upon (and necessarily implied by) the LID. ${ }^{4}$

The law of noncontradiction (hereafter described as LNC), which had again been implicitly accepted by Parmenides, and openly rejected by Heraclitus, was implicitly present in several Platonic dialogues. Plato also explicitly formulated the principle in the Republic:

The same thing clearly cannot act or be acted upon in the same part or in relation to the same thing at the same time, in contrary ways. ${ }^{5}$

In several passages of the Metaphysics, Aristotle formulates the LNC in a logical and ontological form:

It is impossible that the same thing belong and not belong to the same thing at the same time and in the same respect. ${ }^{6}$

The most certain of all basic principles is that contradictory propositions are not true simultaneously. ${ }^{7}$

In logical notation, the LNC could be expressed as $\sim(\mathrm{A} \wedge \sim \mathrm{A})$. In

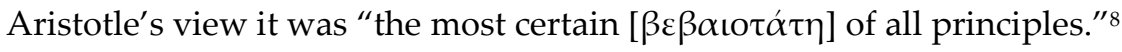
Works, 185ab.

${ }^{3}$ Plato, Theaetetus, trans. by M.J. Levett, rev. by Myles Burnyeat, in Plato: Complete

${ }^{4}$ Aristotle, Metaphysics, trans. by Hugh Tredennick (Cambridge: Harvard University Press, 1933), 1004b.

${ }^{5}$ Plato, Republic, G.M.A. Grube, rev. by C.D.C. Reeve, in Plato: Complete Works, 436b.

${ }^{6}$ Aristotle, Metaphysics, 1005b19-20.

${ }^{7}$ Ibid, 1011b13-14.

8 Ibid, 1005 b24. 
Avicenna was slightly more explicit, claiming that

Anyone who denies the law of noncontradiction should be beaten and burned until he admits that to be beaten is not the same as not to be beaten, and to be burned is not the same as not to be burned. ${ }^{9}$

Indeed, if the LID is accepted in the first place, the LNC cannot but follow as a direct implication. In fact, once the idea of a specific irreducible identity is posed, that same identity cannot but reveal its manifest specificity and irreducibility in respect to all other conceivable entities. In other words, any contingent identity of an entity to itself directly implies the idea of difference of the same entity in respect to any other entity; it does naturally follow that identity and difference, in respect to the same entity, are mutually exclusive, and therefore, contradictory.

In a similar way, the third of these laws, the law of the excluded middle (from now on referred to as LEM) is nothing but a direct consequence of the first two assumptions. Once the notions of identity, and contradictoriness are given as premises, it is clear that any true proposition entails a false negation, and vice versa. As Aristotle puts it, "it will not be possible to be and not to be the same thing." 10 Therefore, the possibility of a third term (the aforementioned "middle") is to be excluded (tertium non datur). Or, again in Aristotle's words,

there cannot be an intermediate between contradictories, but of one subject we must either affirm or deny any one predicate. ${ }^{11}$

The combined set of LID, LNC, and LEM has never been questioned in the domain of formal logic until the early $20^{\text {th }}$ century, when modern developments and ideas led to the formulation of revolutionary forms of logic, such as intuitionistic logic.

However, it is important to note that these principles did not remain enclosed in the narrow field of formal logic. They have been, instead almost unconditionally endorsed within traditional ontological, metaphysical, and even scientific theoretical speculations, following the path traced by Father

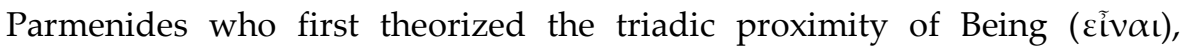

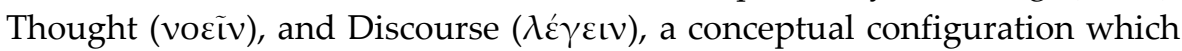

\footnotetext{
9 Avicenna, The Metaphysics of The Healing, trans. by Michael E. Marmura (Provo: Brigham Young University Press, 2005), I.11.105a4-5.

${ }^{10}$ Aristotle, Metaphysics, 1004ab.

${ }^{11} \mathrm{Ibid}, 1007 \mathrm{a}$.

(c) 2017 Rudi Capra

https://www.kritike.org/journal/issue 21/capra december2017.pdf

ISSN 1908-7330
}

(cc) BY-NC-ND 
has exercised a remarkable influence on the historical development of Western philosophy. ${ }^{12}$

In fact, without the adoption of these principles there could have

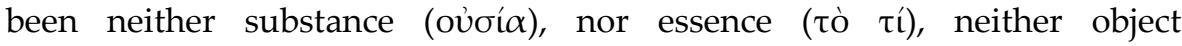

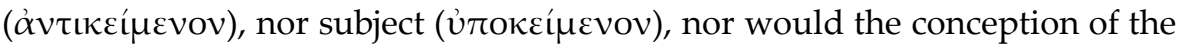
Cartesian ego have been possible.

It is precisely the irrefutable status of the logic of identity (and its implications) in its logical, ontological, psychological usage that has been harshly and repeatedly targeted by the modern and contemporary maîtres $d u$ soupçon: Nietzsche, Freud, Derrida, and Deleuze. ${ }^{13}$ Whereas the Western philosophical tradition mainly developed as a patient construction of majestic theoretical architectures starting from a few solid conceptual grounds, these aforementioned philosophers advocated for a gradual dismantlement of those grounds that, in the meanwhile, had become impenetrable walls, insurmountable limits of thought.

In particular, the general acceptance of the above-described laws led to labelling as absurd, irrational, "poetic" or laughable all theories and philosophical views that would totally or partially reject them. ${ }^{14}$ In the next section, I will briefly expose some fundamental traits of the Buddhist worldview, and illustrate how, without falling into an abyss of nonsense, this view does not offer any ground for endorsing the Western laws of thought.

\section{The Buddhist View}

The fundamental truths of Buddhism seem to have been derived from the simple observation of the natural world. The famous story of the earliest trips of Gautama Buddha out of his palace, when he saw for the first time an old man, a diseased man, and a rotting corpse, regardless of its historical truthfulness, represents a symbolic invitation to any individualan invitation to observe the natural course of the world and consider the

${ }^{12}$ On the centrality of the principle of identity and of Parmenides' influence in respect to the historical development of Western philosophy, see Martin Heidegger, Zur Sache des Denkens (Tübingen: Niemeyer) or Martin Heidegger, On Time and Being, trans. by J. Stambaugh (New York: Harper \& Row, 1972).

${ }^{13}$ In relation to the present issue, see Friedrich Nietzsche, Kritische Studienausgabe (Berlin: de Gruyter, 1999), 9, 11[7]; Sigmund Freud, "The Origin and Development of Psychoanalysis", trans. by Harry W. Chase, in The American Journal of Psychology 21:2 (1910), 181218; and Gilles Deleuze, Différence et Répétition (Paris: PUF, 1968).

${ }^{14}$ Besides the aforementioned criticisms of Zen, it is worth remembering Carnap's renowned and merciless comment of a passage from Heidegger's Being and Time, or Bertrand Russell's petty comments on Nietzsche's philosophy (and on Nietzsche himself), certainly excusable given his poor understanding of the subject. 


\section{IDENTITY AND CONTRADICTION}

evidence that all is impermanent and "whatever is subject to origination is subject to cessation." 15

The universe is then compared to a "decaying old house on fire," and the mission of the Buddha is "to rescue sentient beings from the fire of birth, old age, illness and death, anxiety, sorrow, suffering, distress, delusion, blindness, and the three poisons of greed, hatred, and ignorance."16

In Buddhism, the notion of impermanence (anicca) is one of the three marks of existence, the others being unsatisfactoriness (dukkha) and noselfness (anatta). Leaving aside for the moment the existential implications of the affliction $(d u k k h a)$ caused by the unsatisfying, unreliable nature of things, I will analyze the mutually dependent concepts of impermanence, and of the absence of intrinsic nature, with peculiar attention to the former because it seems to hold an axiomatic position in the (historical and hermeneutic) development of Buddhism. By definition, an axiom is a principle that is accepted to be true by self-evidence, and as I previously claimed, the selfevidence of impermanence is seized from the simple observation of the world. However, an axiom is also a fundamentally undisputed premise on which further arguments can be based.

From this point of view, not only the reality of impermanence is uncontested among all Buddhist schools (whereas other doctrinal elements tend to vary, sometimes greatly), but even among the three marks it seems to retain at least a logical priority. Indeed, the unsatisfactoriness caused by the unreliable nature of things does not necessarily imply that the nature of things is truly unreliable. At the same time, the selflessness of things (and beings) does not necessarily imply that all forms of existence are conditioned phenomena, constantly immersed in a lingering state of transience.

On the contrary, the notion of anicca is clearly incompatible with an essentialist view, and therefore directly implies anatta (but apparently not $d u k k h a)$. In sum, the concept of impermanence has to be considered a fundamental axiom of the Buddhist discourse, because of its irrefutable status and its logical priority over the following doctrinal elaborations.

Since everything is impermanent and devoid of intrinsic nature, in order to describe the universe, Buddhist texts often employ the concept of śūnyatā ("voidness," "emptiness," "nothingness," "openness").

In the Lotus Sutra, the nature of the world is presented thus:

All dharmas are empty and without substance,

${ }^{15}$ The Middle Length Discourses of the Buddha: A Translation of the Majjhima Nikaya (The Teachings of the Buddha), trans. by Bhikku Nanamoli and Bhikku Bodhi (Soomerville: Wisdom, 1995), 56.

${ }^{16}$ The Lotus Sutra, trans. by Tsugunari Kubo and Akira Yuyama (Berkeley: Numata Center for Buddhist Translation and Research, 2007), 13a.

(C) 2017 Rudi Capra

https://www.kritike.org/journal/issue 21/capra december2017.pdf

ISSN 1908-7330

(c) $)$ BY-NC-ND 
Impermanent, without origination or cessation.

This is known as the sphere

Of the relationships of the wise.

Through the error of discrimination

One sees all existent things

As existing or nonexisting,

Real or unreal,

Produced or unproduced.

[...]

He [the bodhisattva] should regard all dharmas

As being without substance,

Like empty space

Which has no firmness.

All dharmas are neither produced

Nor do they emerge;

They are immovable, nonreturning,

And always remain in their single character.

This is known as the sphere of relationships. ${ }^{17}$

The first passage is particularly critical of the deceptive effect of the discriminating mind, which operates by applying on reality illusory dichotomies (of existing/nonexisting, real/unreal, produced/unproduced). In fact, since the universe is a constant flux in which all aggregates are gradually dissolved while new ones gradually emerge, any perceivable distinction is ultimately relative. Also, anything that is, and ceases to be, is neither created ex nihilo nor extinct in nihilo. If nothing is generated and nothing is destroyed within the universal law of impermanence, then, in a wider sense, all dharmas, perpetually in motion, are "immovable," since they "always remain in their single character." Furthermore, the reality of dharmas is explicitly compared to an "empty space which has no firmness," and is "without substance."

The Diamond Sutra, whose poetic and imaginative style was greatly influential in the Zen tradition, contains the famous gatha:

All conditioned dharmas

Are like dreams, illusions, bubbles, shadows,

Like dew drops and a lightning flash:

Contemplate them thus. ${ }^{18}$

${ }^{17}$ Ibid, 37c.

${ }^{18}$ The Diamond of Perfect Wisdom Sutra, trans. by the Chung Tai Translation Committee, in Bao Lin Chan Monastery - Zen Center of Melbourne, < $\underline{\text { http://chungtai.org.au/en/wp- }}$

(c) 2017 Rudi Capra

https://www.kritike.org/journal/issue 21/capra december2017.pdf

ISSN 1908-7330

(cc) BY-NC-ND 
The "conditioned dharmas" indicate all events and activities: empirical senses, mental processes, entities and forms, material elements. Everything in the universe is a conditioned dharma, and comparable to dreams, illusions, and shadows, phenomena which are real in a broad sense (since something is occurring) but unreal in the ordinary sense of the term (since what is truly occurring is different from what seems to occur).

Conditioned dharmas are comparable to bubbles, dew drops, and lightning flashes, phenomena that arise as rapidly as they vanish. Once more, it is claimed that the "true nature of reality is empty. This is what the Tathagata calls the true nature of reality." 19

Similarly, in the Vimalakìrti Nirdeśa Sūtra, we read, "All constructed things are impermanent." ${ }^{20}$ And "nothing was ever destroyed, is destroyed, or will ever be destroyed. Such is the meaning of 'impermanence.'" 21 Even in this case, the notion of impermanence directly implies that all things and phenomena lack an inherent nature: "This world has the nature of voidness". 22

It is important to note that the Buddhist void (śunnyatā) is by no means

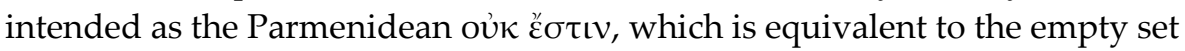
of possible thoughts beyond the inherent limits of thinkability, which is equivalent to a formal representation of the paradoxical nature of what-isnot. ${ }^{23}$

On the contrary, according to the Buddhist world view, śunyatā is only apparently paradoxical. Instead it lies in the processual core of reality, constituting its veritable character: "Matter itself is void. Voidness does not result from the destruction of matter, but the nature of matter is itself voidness." 24

Matter is void not because it is nonexistent, but in the sense that "that physical appearances are actually not physical appearances." 25 Physical appearances are ultimately subject to permutation and dissolution; they lack any sort of stable essence, tò $\tau i$, haecceity, irreducible ego or consciousness. Put briefly, all things are impermanent; all compounded things have no Self.

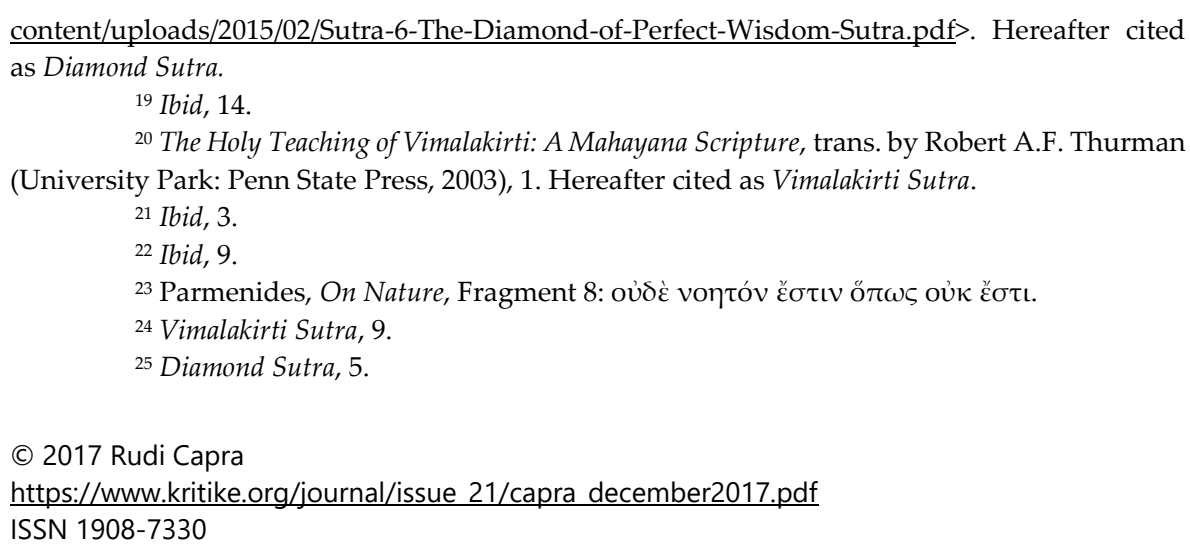


Particularly, the critique of the idea of a stable intrinsic nature (svabhāva) finds its most brilliant (and explicit) philosophical formulation in the Madhyamaka school, whose founder Nāgārjuna is regarded by many as the hypothetical "unofficial First Patriarch" of Zen Buddhism. By systematically recurring to the prominent figure of Indian classical logic, the tetralemma, Nāgārjuna criticized all forms of essentialism. Specifically, he challenged the essentialist view of Abhidharma that had consistently grown in popularity among Buddhists disciples. ${ }^{26}$

In Nāgārjuna's corpus

svabhāva is by definition the subject of contradictory ascriptions. If it exists, it must belong to an existent entity, which means that it must be conditioned, dependent on other entities, and caused. Nevertheless, svabhāva is by definition unconditioned, not dependent on other entities, and not caused. Thus the existence of svabhāva is impossible. ${ }^{27}$

Since everything that exists is conditioned, depending upon a multiple set of causes and relationships, the absence of intrinsic nature is thus explicitly equated to the principle of pratityasamutpāda. The term is translatable as "dependent origination," "dependent arising," "interdependent co-arising," "conditioned arising," "conditioned genesis," "causal interdependence," and more literally, "arising according to dependence upon causal conditions." It is poetically exemplified by the metaphor of Indra's net:

Far away in the heavenly abode of the great god Indra, there is a wonderful net which has been hung by some cunning artificer in such a manner that it stretches out infinitely in all directions. In accordance with the extravagant tastes of deities, the artificer has hung a single glittering jewel in each eye of the net, and since the net itself is infinite in dimension, the jewels are infinite in number. There hang the jewels, glittering like stars in the first magnitude, a wonderful sight to behold. If we now arbitrarily select one of these jewels for inspection and look closely at it, we will discover that in

\footnotetext{
${ }^{26}$ Even though in the earlier formulations of Abhidharma's doctrine, "svabhāva" is employed as a criterion that determines what a dharma is, not necessarily that a dharma exists.

${ }^{27}$ Richard H. Robinson, "Some Logical Aspects of Nāgārjuna's System" in Philosophy East $\mathcal{E}$ West, 6:4 (1957), 301-313.
} 
its polished surface there are reflected all the other jewels in the net, infinite in number. Not only that, but each of the jewels reflected in this one jewel is also reflecting all the other jewels, so that there is an infinite reflecting process occurring. ${ }^{28}$

A different interpretation of the Buddha's teachings was offered by the Yogachara school, which was also very influential on the historical development of Zen. In respect to the Madhyamaka school, criticized for its "nihilistic" description of reality, Yogacarins stressed the idea that consciousness (vijñana) is the only reality, and all phenomena only exist as appearances. ${ }^{29}$ According to this view, the entire system of mentation is naturally predisposed to accumulate and substantialize multiple perceptions, thus creating the illusion of a persistent self.

In the Yogachara's perspective, śūnyatā does not necessarily refer to physical phenomena. Instead, it represents the final dissolution of the limit that divides the subject and the object, causing the "awakening" (bodhi). Śünyatā dwells in the consciousness - although consciousness is not regarded as a self-subsistent entity. Although Tibetan sources present the Yogachara and Madhyamaka as rival schools, modern scholars tend present these views as complementary interpretations. ${ }^{30}$

However, the Buddhist Weltanschauung is grounded on the notion of impermanence (anicca), which implies (or coincides with) the absence of intrinsic nature (anatta). All aggregates arising and ceasing within this dynamic context of perpetual transformation are basically interconnected and mutually dependent on causal conditions (pratītyasamutpāda). Since all phenomena lack intrinsic nature, intrinsic reality, intrinsic identity, and intrinsic referentiality (svabhāva), the fundamental nature of phenomena is empty (śūnyatā). The spontaneous action of consciousness (vijñanna) tends to see them as if they were self-subsistent.

What is important to note, is that the constitutive lack of "self" or "intrinsic nature" described by Buddhism unavoidably deprives of universal validity the application of those principles that served as a basis for the philosophical research in the West. According to the Buddhist view, any apparent object (or subject) is the result of several complex dynamic

${ }^{28}$ Francis H. Cook, Hua-Yen Buddhism: The Jewel Net of Indra (University Park: Penn State Press, 1977), 7.

${ }^{29}$ Madhyamaka was deemed "nihilistic" by some Yogacharins since the exponent of the Madhyamaka school apparently posed the dharma "in the Void". See for instance Dan Lusthaus, Buddhist Phenomenology: A Philosophical Investigation of Yogacara Buddhism and the Ch'eng Wei-shih Lun (London: Routledge, 2002).

${ }^{30}$ On this topic, see Edward Conze, A Short History of Buddhism, (London: Oneworld, 1993).

(C) 2017 Rudi Capra

https://www.kritike.org/journal/issue 21/capra december2017.pdf

ISSN 1908-7330

(c) ) BY-NC-ND 
interactions, exactly as a color is nothing but the result of the interaction of physical light receptors with the electromagnetic spectrum.

Indeed, the interpenetration of all things, and their ultimate transitory nature prevent any attempt at individuating or defining a single, persistent identity, dependent neither on spatial nor temporal conditions for its own existence. In this sense, the LID obviously has to be rejected, together with its corollaries and implications. Any Buddhist philosopher would probably disagree with Parmenides on the mutual exclusiveness of contraries, and agree instead with the Heraclitean utterance that a man cannot step twice into the same river, since both the river, and the man are subject to the ever-changing flux of time.

In the following paragraphs, I consider Zen Buddhism and its renowned use of paradoxical images and absurd statements. By exposing relevant notions concerning the nature of language and consciousness according to Zen, I illustrate a peculiar logical formula that can be found in several texts belonging to the Zen literary tradition, concerning specifically the concept of contradiction.

\section{Zen and the Logic of Nothingness}

Zen has been widely described, within and outside the context of academia, as a "cult of the absurd," by detractors, and even by zealous disciples. ${ }^{31}$ For instance, Suzuki evoked Tertullian's paradox (credo quia absurdum) in order to explain Zen's faith in irrationality. Actually, the view of Zen as an anti-rational and anti-intellectual tradition has been challenged. ${ }^{32}$

${ }^{31}$ Arthur Koestler, “A Stink of Zen: The Lotus and the Robot II" in Encounter 85 (1960), 13-32.

${ }^{32}$ Daisetsu Teitaro Suzuki, Comparative Religion, ed. by Jeff Wilson and Tomoe Moriya, vol. 3 of Selected Works of D.T. Suzuki (Berkeley: University of California Press), 123.

Zen has often been described as a chiefly anti-intellectualist tradition. Nonetheless, this is only partially true: recent studies explored Zen insistence on the intuitive and "sudden" character of the true understanding and the alleged rejection of pedagogical mediations, identifying this emphasis as the result of a rhetorical strategy and not as the reflection of an actual praxis. See Bernard Faure, The Rhetoric of Immediacy (Princeton: Princeton University Press, 1991) and Youru Wang, Linguistic Strategies in Daoist Zhuangzi and Chan Buddhism (New York: Routledge, 2003).

In addition, although Zen is supposed to be a "special transmission outside the scriptures" (jiaowai biechuan 教外別傳), several studies proved that Mahayana teachings, doctrines and sutras were greatly influential in Chan, since its early origins. See Albert Low, Zen and the Sutras (Boston: Turtle Publishing 2000).

Several schools and lineages emphasized, in relation to the idea of a "special transmission outside the scriptures", the complementary principle of "harmony between Chan and the teachings" (jiaochan yizhi 教禪一致). See Albert Welter “Mahakasyapa's Smile: Silent Transmission and the Kung-an (Koan) Tradition," in The Koan: Texts and Contexts in Zen Buddhism, ed. by Steven Heine and Dale S. Wright (Oxford: Oxford University Press 2000).

(c) 2017 Rudi Capra

https://www.kritike.org/journal/issue 21/capra december2017.pdf

ISSN 1908-7330

(cc) BY-NC-ND 


\section{IDENTITY AND CONTRADICTION}

Among the most popular epitomes of Zen as mask of the absurd and of the incomprehensible, there is certainly the saying of Qingyuan Weixin 青原惟信 , master who lived in the $9^{\text {th }}$ century:

Before I had studied Zen for thirty years, I saw mountains as mountains, and rivers as rivers. When I arrived at a more intimate knowledge, I came to the point where I saw that mountains are not mountains, and rivers are not rivers. But now that I have got its very substance I am at rest. For it is just that I see mountains once again as mountains, and rivers once again as rivers. ${ }^{33}$

A similar pattern repeatedly occurs in the Diamond Sutra:

Subhuti, that which is called the Buddha Dharma is not the Buddha Dharma; therefore it is called the Buddha Dharma. ${ }^{34}$

The Buddha teaches that prajna paramita [perfection of wisdom] is not prajna paramita. Therefore it is called prajna paramita. ${ }^{35}$

To the extent that these worlds really exist, they do so as a composite. The Tathagata teaches that composites are not composites. Therefore they are called composites. ${ }^{36}$

In order to explain the peculiar logic that underlies these sayings, I need to say something more about the pedagogic process inherent to the Zen experience, necessarily transmitted from masters to disciples, "mind-tomind" (以心伝心 ishin denshin).

Until now, I illustrated the Buddhist view of the world as based on the notion of impermanence, selflessness and arising co-dependence. What I omitted to explain in detail is that the transitory, empty character of reality provokes a persistent state of unsatisfactoriness, suffering or anxiety $(d u k k h a)$. This happens because the mind is naturally predisposed to "essentialize" perceptions and thoughts, and merge them in a coherent view. These accumulations of perceptions and thoughts, grasped by the senses, and

\footnotetext{
${ }^{33}$ Alan Watts, The Way of Zen (New York: Pantheon Books, 1951), 26.

${ }^{34}$ Diamond Sutra, 8.

${ }^{35} \mathrm{Ibid}, 13$.

${ }^{36} \mathrm{Ibid}, 30$.

https://www.kritike.org/journal/issue 21/capra december2017.pdf
}

(C) 2017 Rudi Capra

ISSN 1908-7330

(c) BY-NC-ND 
sedimented by the action of consciousness and memory, create the illusion of countless external substances opposing a singular internal substance, the ego, thus developing multiple (noxious) attachments. The accomplished sedimentation of senses-thoughts within the achieved construction of a self thus generates a state of $d u k k h a$, and prevents the opportunity of seeing things as they are.

Within this theoretical framework, the use of language does not only reveal the presence of mental hindrances, but also actively contributes in the generation of further obstacles:

Word-discrimination goes on by the coordination of brain, chest, nose, throat, palate, lips, tongue, teeth and lips. Words are neither different nor not-different from discrimination. Words rise from discrimination as their cause; if words were different from discrimination they could not have discrimination for their cause; then again, if words are not different, they could not carry and express meaning. Words, therefore, are produced by causation and are mutually conditioning and shifting and, just like things, are subject to birth and destruction. ${ }^{37}$

In Zen, non-verbal teachings are often preferred, since an imprudent use of language may generate additional illusions instead of dissolving the former ones. In this sense, Zen's approach is analogous to Wittgenstein's claim that philosophical problems must be dissolved rather than solved, since they spontaneously arise within the ordinary functioning of language - and, in the case of Zen, within the ordinary functioning of the whole system of mind, language, senses, and consciousness.

Indeed, the target of Zen is not merely the language. Instead, it is necessary to destabilize the discriminating action of consciousness. The primary task of the Zen master is to bring the disciple back to a pre-logical and pre-conceptual dimension of consciousness, emptying the mind from noxious obstructions.

The final result of this process is the experience of the state of no-mind (無心 mushin), characterized by no-thinking (無念 munen), which is not to be intended as a state of torpidity or inertness, but contrarily, as a psychological state "in which the mind finds itself at the highest point of tension, a state in which the mind works with utmost intensity and lucidity", and reality is

${ }^{37}$ Lankavatara Sutra, in A Buddhist Bible, ed. by Dwight Goddard (Boston: Beacon Press, 1996), 2.

(c) 2017 Rudi Capra

https://www.kritike.org/journal/issue 21/capra december2017.pdf

ISSN 1908-7330

(c) BY-NC-ND 
finally seized in the fullest density of existence, in its non-discriminated "suchness" (真如 shinnyo). 38

Good friends, what is negated by the "non" (無 $m u$ )? What kind of thing is "thought" (念 nen)? "Non" means to be without the characteristic of duality, to be without the mind of the enervating defilements. "Thought" is to think of the fundamental nature of suchness. ${ }^{39}$

Nonetheless, Zen does not advocate for a complete retirement from the "ordinary" world and a complete rejection of the ordinary state of consciousness, of the ordinary use of language, of the appeal to ordinary rationality, of the ordinary functioning of the mind. On the contrary, Zen advocates for the mastery of both these existential dimensions, the "conventional" and the "ultimate" realm. ${ }^{40}$ Several mondo (Zen dialogues) and koan narratives are structured upon the ideal interplay between conventional and ultimate truths.

A remarkable difficulty in interpreting Zen scripts and sayings is due to their intrinsically perspectival standpoint. As was previously mentioned, according to Buddhism, even if the ultimate nature of the world consists in a state of dynamic non-determined nothingness, the same idea of nothingness must not become the object of a conceptual or emotional attachment. ${ }^{41}$

In other words, a Zen practitioner should always be able to grasp reality in its totalizing contradictoriness and never dwell either in the realm of ultimate existence or in the complementary realm of conventional existence. Whenever this happens, the Zen master reacts by preaching the complementary pole of any antithesis generated by the spontaneous action of the discriminating mind:

Because we maintain our minds of impermanence, The Buddha preached of permanence. ${ }^{42}$

After having clarified these notions, we are finally able to understand the statement of Qingyuan Weixin and the logic of the Diamond Sutra, without the necessity of dismissing them as absurd or nonsensical.

\footnotetext{
${ }^{38}$ Toshihiko Izutsu, Toward a Philosophy of Zen Buddhism (Boston: Shambhala, 1982), 14.

${ }^{39}$ Huineng, The Platform Sutra of the Sixth Patriarch, trans. by John McRae (Berkeley: Numata Center for Buddhist Translation and Research, 2000), 353ab.

${ }^{40}$ This idea is not an original product of Zen, it was already advanced in the Pali Canon, for instance in the Anguttara Nikaya, and in the Madhyamaka School.

${ }^{41}$ Huineng, The Platform Sutra of the Sixth Patriarch, 359b.

${ }^{42}$ Ibid., 350a.

(c) 2017 Rudi Capra

https://www.kritike.org/journal/issue 21/capra december2017.pdf

ISSN 1908-7330
}

(c) BY-NC-ND 
The logical principle underlying these texts can thus be expressed by the formula: $\mathbf{A}$ is not $\mathbf{A}$, therefore it is $\mathbf{A}$.

The first " $\mathrm{A}$ " refers to phenomena as they are perceived according to the ordinary state of consciousness, i.e. a state of mind in which things, including the ego, are seen as independently existent since provided with a specific irreducible identity.

This step is immediately negated by the following, "is not A". Within the Buddhist perspective, every aggregate relies on multiple causes and maintains multiple relationships with a wide spectrum of other processes. ${ }^{43}$ Due to these reasons, a single aggregate could be ideally isolated in conventional terms (in the domain of the Buddhist "conventional truth"), but never in theoretical or doctrinal terms (in the domain of the complementary "ultimate truth").

For instance, the simple consideration of a blade of grass would necessarily imply references to the soil in which it is planted, to the air, to water, to the atmosphere, and each of these elements would bring further connections and relationships, to such an extent that it would not be possible to graze a single blade of grass without influencing, at the same time, the entire universe.

Nothing, according to Buddhism, is independently existent, and therefore it would be utterly nonsensical to define anything without considering the infinite set of co-dependent relationships connecting every single part to the whole. Furthermore, any conditioned dharma has to be regarded as a lightning flash or a dewdrop.

Therefore, since any aggregate is immersed in the flux of time, it lacks an intrinsic essence that would allow a permanent identification and, consequently, a positive definition.

For these reasons, the LID does not apply in the Buddhist perspective. Even positing only " $\mathrm{A}$ " would be, in principle, unacceptable, since there is nothing identical to itself: firstly, because there is nothing at all, being any apparent entity is merely the result of a countless number of processual interactions; secondly, because the flowing of time frustrates any attempt at determining or attributing a stable identity to any conceivable A.

From this standpoint, it is not even contradictory to equate any term to its negation, nor to reaffirm the negated term right after its denial. If there is no identity, there is also no difference, since only something provided with a specific identity can be different from something else. Where there is no difference, there cannot be any contradiction. Thus, this view does not offer any ground for endorsing even the LNC and, evidently, the LEM. vocabulary.

${ }^{43}$ Any physical aggregate, i.e., any "object" or "entity" in a Western philosophical 


\section{6}

\section{IDENTITY AND CONTRADICTION}

Despite that, the formula "A is not A", as "mountains are not mountains" or "rivers are not rivers," can be easily explained given a basic account of Zen view of the world: phenomena which appears to be existing as self-sufficient entities are actually devoid of inherent existence and not isolable as such. The proposition " $\mathrm{A}$ is not $\mathrm{A}$ " opposes then the conventional truth, i.e. the ordinary state of consciousness in which a permanent selfidentical ego is ideally counter-posed to a realm populated by likewise permanent self-identical entities, to the ultimate truth, i.e. a state of consciousness in which reality and the manifold aggregates are perceived as non-determined nothingness.

Nonetheless, although " $\mathrm{A}$ is not $\mathrm{A}$, " it is reaffirmed that "therefore it is $\mathrm{A}^{\prime \prime}$. In fact, ultimate and conventional truth, ordinary and not-ordinary states of consciousness are not mutually exclusive, but complementary. Once acknowledged, the significant difference between conventional and ultimate truth must be overcome. If one remains attached either to the ordinary world or "to emptiness" his experience of Zen will be defective or faulty, contaminated by a noxious form of one-sidedness. Zen does not advocate an escape from reality, but rather for a more complete and totalizing experience of it.

Therefore, the reaffirmation of "therefore it is A" also reaffirms the necessity to live, to reason and to communicate through the language, despite its inherent impossibility to construct meaningful descriptions of the world at least, in respect to the ultimate truth, which is by definition ungraspable and undefinable.

Finally, at the beginning "seeing mountains as mountains and rivers as rivers" means the common, ordinary understanding of reality. Then, "seeing mountains as not mountains and rivers as not rivers" means to have grasped the processual nothingness behind all phenomena. Lastly, "seeing again mountains as mountains and rivers as rivers" means to have subsumed the contradictoriness of reality ${ }^{44}$ in a state of consciousness able to embrace and transcend all conceivable contradictions.

It is now clear how the Zen standpoint (consisting actually in a differential abandonment of all standpoints) cannot be considered as merely illogical or absurd. Rather, it stands outside of a particular logic, namely the logic of identity, and contradiction that underlay the historical development of the Western philosophical discourse.

Zen's own logic transcends the dichotomous construction of dualistic couples of identities and contradictions, and is clearly represented by the

${ }^{44}$ To claim that things themselves are inherently contradictory is not only a rather odd affirmation, but also a completely misleading one according to the Buddhist perspective. Obviously, the contradiction must lie, or rather it must have been produced, within the ongoing relationship between things and the mind.

(c) 2017 Rudi Capra

https://www.kritike.org/journal/issue 21/capra december2017.pdf

ISSN 1908-7330

$((c))$ BY-NC-ND 
(apparently) paradoxical formula "A is not A, therefore it is A." Following Nishida Kitarō, this principle could be given the denomination of SelfIdentity of Contradiction (SIC). ${ }^{45}$

\section{Conclusion}

To begin with, I illustrated the fundamental principles of the Western classical logic, which have been implicitly accepted throughout the history of Western philosophy and formal ontology. Subsequently, I criticized the characterization of Zen as an epitome of the absurd, a persistent platitude that has been repeated even by Zen scholars in order to stress an antithetic and irreconcilable opposition between the Western and the East Asian philosophical traditions.

After having described the fundamental assumptions of Buddhism and a number of important notions pertinent to Zen theory and praxis, I analyzed and explained a peculiar formula that appears to be recurrent in several Zen literary sources, from ancient sutras to modern treatises.

I hope in this way to have demonstrated that, although violating the principles of Western classical logic ultimately based on the mutually dependent notions of identity and contradiction, the logic of the "self-identity of contradiction" cannot be criticized (or praised) for being absurd or illogical.

Department of Philosophy, University College Cork, Ireland

\section{References}

Aristotle, Metaphysics, trans. by Hugh Tredennick (Cambridge: Harvard University Press, 1933).

Avicenna, The Metaphysics of The Healing, trans. by Michael E. Marmura (Provo: Brigham Young University Press, 2005).

Conze, Edward, A Short History of Buddhism, (London: Oneworld, 1993).

Cook, Francis A., Hua-Yen Buddhism: The Jewel Net of Indra (University Park: Penn State Press, 1977).

Deleuze, Gilles, Différence et Répétition (Paris: PUF, 1968).

Faure, Bernard, The Rhetoric of Immediacy (Princeton: Princeton University Press, 1991)

Freud, Sigmund, "The Origin and Development of Psychoanalysis", trans. by Harry W. Chase, in The American Journal of Psychology 21:2 (1910).

\footnotetext{
${ }^{45}$ More precisely, the "logic of absolutely contradictory self-identity" (zettai mujunteki jikodōitsu no ronri) is a key notion of Nishida Kitarō's complex philosophical system.

(C) 2017 Rudi Capra

https://www.kritike.org/journal/issue 21/capra december2017.pdf

ISSN 1908-7330 
Heidegger, Martin, On Time and Being, trans. by J. Stambaugh (New York: Harper \& Row, 1972). Zur Sache des Denkens (Tübingen: Niemeyer).

Huineng, The Platform Sutra of the Sixth Patriarch, trans. by John McRae (Berkeley: Numata Center for Buddhist Translation and Research, 2000

Lankavatara Sutra, in A Buddhist Bible, ed. by Dwight Goddard (Boston: Beacon Press, 1996).

Low, Albert, Zen and the Sutras (Boston: Turtle Publishing 2000).

Koestler, Arthur, "A Stink of Zen: The Lotus and the Robot II" in Encounter 85 (1960)

Lusthaus, Dan, Buddhist Phenomenology: A Philosophical Investigation of Yogacara Buddhism and the Ch'eng Wei-shih Lun (London: Routledge, 2002).

Nietzsche, Friedrich, Kritische Studienausgabe (Berlin: de Gruyter, 1999).

Parmenides, On Nature (fragments), in Herman Diels and Walther Kranz, Die Fragmente der Vorsokratiker (Berlin: Weidmann, 1974).

Plato, Republic, G.M.A. Grube, rev. by C.D.C. Reeve, in Plato: Complete Works, ed. by John M. Cooper and Douglas S. Hutchinson (Indianapolis: Hackett, 1977). Sophist, trans. by Nicholas P. White, in Plato: Complete Works, ed. by John M. Cooper and Douglas S. Hutchinson (Indianapolis: Hackett, 1977). Theaetetus, trans. by M.J. Levett, rev. by Myles Burnyeat, in Plato: Complete Works, ed. by John M. Cooper and Douglas S. Hutchinson (Indianapolis: Hackett, 1977).

Robinson, Richard H., "Some Logical Aspects of Nāgārjuna's System" in Philosophy East \& West, 6:4 (1957).

Suzuki, Deisetsu Tetaro, Comparative Religion, ed. by Jeff Wilson and Tomoe Moriya, vol. 3 of Selected Works of D.T. Suzuki (Berkeley: University of California Press).

The Diamond of Perfect Wisdom Sutra, trans. by the Chung Tai Translation Committee, in Bao Lin Chan Monastery - Zen Center of Melbourne, $<$ http://chungtai.org.au/en/wp-content/uploads/2015/02/Sutra-6The-Diamond-of-Perfect-Wisdom-Sutra.pdf $>$.

The Holy Teaching of Vimalakirti: A Mahayana Scripture, trans. by Robert A.F. Thurman (University Park: Penn State Press, 2003), 1.

The Lotus Sutra, trans. by Tsugunari Kubo and Akira Yuyama (Berkeley: Numata Center for Buddhist Translation and Research, 2007).

The Middle Length Discourses of the Buddha: A Translation of the Majjhima Nikaya (The Teachings of the Buddha), trans. by Bhikku Nanamoli and Bhikku Bodhi (Soomerville: Wisdom, 1995).

(c) 2017 Rudi Capra

https://www.kritike.org/journal/issue 21/capra december2017.pdf

ISSN 1908-7330

(cc) BY-NC-ND 
Toshihiko Izutsu, Toward a Philosophy of Zen Buddhism (Boston: Shambhala, 1982).

Wang, Youru, Linguistic Strategies in Daoist Zhuangzi and Chan Buddhism (New York: Routledge, 2003).

Watts, Alan, The Way of Zen (New York: Pantheon Books, 1951)

Welter, Albert, "Mahakasyapa's Smile: Silent Transmission and the Kung-an (Koan) Tradition," in The Koan: Texts and Contexts in 